Vol 11, Issue 3, 2018

\title{
PHYTOCHEMICAL ANALYSIS, LIQUID CHROMATOGRAPHY, AND MASS SPECTROSCOPY AND IN VITRO ANTICANCER ACTIVITY OF ANNONA SQUAMOSA SEEDS LINN.
}

\author{
SHUCHI DAVE MEHTA*, SARVESH PALIWAL
}

Department of Pharmacy, Banasthali University, Jaipur, Rajasthan, India. Email shuchi_dave@yahoo.com

Received: 28 September 2017, Revised and Accepted: 16 November 2017

\section{ABSTRACT}

Objective: The objective of the present study is to evaluate in vitro anticancer property and phytochemical analysis using liquid chromatography and mass spectroscopy (LCMS) method of hydroalcoholic extract of seeds of Annona squamosa (AS) Linn. Seeds of AS Linn. are traditional medicine treating various diseases and have shown anticancer activity. Due to lack of survival benefit, cancer is a deadly global disease.

Method: The anticancer activity was evaluated using the sulforhodamine B assay method on five cancer cell lines: Breast cancer cell line, cervix cancer cell line (SiHa), colon cancer cell line (HT)-29, liver cancer cell line, and ovary cancer cell line (Ovcar). The phytochemical analysis was performed using LCMS method.

Result: The phytochemical characterization was done using LCMS method which showed 15 different molecular weight compounds. The extract showed an average in vitro anticancer activity at a concentration of $100 \mu \mathrm{g} / \mathrm{ml}$ against all cancer cell lines. The best activity was observed against Ovcar-5 cell line (69.72) and was also significant against HT and SiHa cell lines.

Conclusion: The phytochemical analysis showed the wide range of phenols and flavonoid which are showing potent anticancer activity of AS seeds.

Keywords: Annona squamosa, Phytochemicals, In vitro anticancer, Liquid chromatography and mass spectroscopy.

(C) 2018 The Authors. Published by Innovare Academic Sciences Pvt Ltd. This is an open access article under the CC BY license (http://creativecommons. org/licenses/by/4. 0/) DOI: http://dx.doi.org/10.22159/ajpcr.2018.v11i3.22808

\section{INTRODUCTION}

Cancer is one of the leading causes of death worldwide. According to the WHO (2004), $12.5 \%$ of the population dies due to cancer. The disease is characterized by the uncontrolled and abnormal growth of cells in the human body, forming tumors of malignant cells with the potential to be metastatic $[1,2]$. Major causes of cancer may be physical inactivity, heredity, unbalanced diet, and various environmental factors [3].

Currently, chemotherapy, radiotherapy, and immunotherapy treatments and surgery cause several toxic effects on non-targeted cells/tissues. This arouses the need of using alternative treatments and therapies against cancer [1,4]. Numerous cancer research studies have been conducted using traditional medicinal plants in an effort to discover new therapeutic agents that lack the toxic side effects associated with the present chemotherapeutic agents [5]. Over the past decades, herbal medicines have made an impact on both global health, and they have been well accepted worldwide [6].

Medicinal plants play a critical role in the healthcare system of a majority of the world's population. Among several medicinal plants worldwide, including India, only a few medicinal plants have attracted the interest of scientists to investigate the remedy for the prevention and treatment of cancer [5]. Natural bioactive compounds such as phenol and flavonoids occurring in the medicinal plants protect the biological systems against harmful effect. They have been studied for their antitumor, proapoptotic, and antiangiogenic effects $[7,8]$.

In history, plant secondary metabolite derives anticancer constituents such as vincristine, vinblastine, camptothecin, podophyllotoxin, flavopiridol, and silvestrol have been used worldwide [9]. Medicinal plants possess good immunomodulatory and antioxidant properties, leading to anticancer activities. The antioxidant phytochemicals protect the cells from oxidative damage. Further, it will be of great significance to develop new drugs from these medicinal plants. Taking into consideration the above facts, an attempt has been made to evaluate the in vitro anticancer activity particularly against totally unexplored ovarian cancer cell lines i.e. SiHa cervix and ovcar-5 ovary cancer cell lines and phytochemical study of the seeds of Annona squamosa more over LCMS analysis will be the part of study.

\section{METHOD}

\section{Chemicals and drugs}

The following drugs and chemicals were used: Ethanol, Roswell Park Memorial Institute (RPMI) media, trypsin-EDTA (Sigma Chemical Co.), fetal bovine serum, penicillin, streptomycin, phosphate-buffered saline, sulforhodamine $\mathrm{b}$, and dimethyl sulfoxide (DMSO). All chemicals used were of analytical grade.

\section{Plant material}

The seeds of AS were obtained from Botanical Garden, Dr. H. S. Gour University, Sagar, M.P, specimen No. BOT/H/12/14/20.

\section{Extract preparation}

The seeds of AS were washed with running water to remove impurities. It was dried to avoid the growth of microorganisms and reduced to coarse powder and subjected to hydroalcoholic extraction with the help of a Soxhlet apparatus. The hydroalcoholic extract was filtered, concentrated under reduced pressure, and lyophilized for drying. The dried extract was kept in the airtight container and stored at $4^{\circ} \mathrm{C}$ till further studies. The air-dried seeds $(150 \mathrm{~g})$ were powdered and then extracted with $1 \mathrm{~L}$ of $50 \%$ ethanol using Soxhlet apparatus at $68^{\circ} \mathrm{C}[10]$. Percentage yield was calculated (Table 1).

\section{Phytochemical tests}

Phytochemical analysis was performed to detect various compounds such as tannins, flavonoids, alkaloids, and steroids [11,12]. 
Table 1: Percentage yield of hydroalcoholic extract of the plant

\begin{tabular}{llllllll}
\hline Solvent & Plant & Part used & Dry weight $(\mathbf{g})$ & Yield $(\mathbf{g})$ & Time $(\mathbf{h})$ & Temperature $\left({ }^{\circ} \mathbf{C}\right)$ & \% yield \\
\hline $50 \%$ ethanol & AS & Seeds & 150 & 25.25 & 96 & 68 & 16.83 \\
\hline AS: Annona squamosa & &
\end{tabular}

Liquid chromatography and mass spectroscopy (LCMS) analysis Seeds of AS were subjected to LCMS analysis using the instrument, Mass Hunter SG11251102 (Agilent Technologies), which was conducted in both polarities (positive and negative) of electron spray ionization (ESI) mode. Better response was found in positive ESI. Two solvents system, i.e. Solvent A (water $+0.1 \%$ formic acid) and Solvent B (acetonitrile) with column Chromolith $-50 \times 4.6 \mathrm{~mm}$ were used for analysis. The fragmentor voltage $135 \mathrm{~V}$, run time $30 \mathrm{~min}$, and flow rate $0.5 \mathrm{ml} /$ min were maintained $[13,14]$. In a total run of $30 \mathrm{~min}$ in the LCMS, approximately 16 compounds were detected. Their retention time and mass have been confirmed (Table 2).

\section{Anticancer activity}

The in vitro anticancer activity of hydroalcoholic extract of seeds of AS was performed on five human cancer cell lines, i.e., human breast adenocarcinoma breast cancer cell line, human cervix cancer cell line (SiHa), colon cancer cell line (HT-29), liver cancer cell line, and ovary cancer cell line (Ovcar-5) which were procured from Regional Research Laboratory, Council of Scientific and Industrial Research, Jammu (J \& K). The cell lines were cultured in RPMI containing 20\% fetal calf serum, 2 $\mathrm{mM}$ l-glutamine, $100 \mathrm{U} / \mathrm{ml}$ penicillin, and $100 \mathrm{~g} / \mathrm{ml}$ streptomycin. All cell lines were maintained at $37^{\circ} \mathrm{C}$ in $5 \% \mathrm{CO}_{2}$ atmosphere with $95 \%$ humidity. Maintained cultures were passaged weekly, and the culture medium was changed twice a week.

In vitro anticancer activity by sulforhodamine B (SRB) assay method

The protocol was established by the National Cancer Institute $[15,16]$ for human tumor cytotoxicity for the assessment of growth inhibition. The colorimetric assay estimated cell number indirectly by staining total cellular protein with the dye SRB. Single-cell suspensions were prepared by the treatment of cells with $0.51 \mathrm{ml}$ of $0.1 \%$ trypsin-EDTA (Sigma Chemical Co.). The viable cells were counted using a Coulter counter and diluted with RPMI medium, and final densities of $100 \times 10^{4}$ cells $/ \mathrm{ml}$ were obtained. Cell suspensions $(100 \mu \mathrm{l} /$ well $)$ were seeded in 96 -well microtiter plate containing $1 \mathrm{ml}$ of media and incubated for cell attachment. After $24 \mathrm{~h}$, the cells were treated with the extracts. Extract was initially dissolved in $100 \%$ DMSO (1 mg/ml for extract) and further diluted in RPMI medium to produce a concentration of $100 \mu \mathrm{g} / \mathrm{ml} .100 \mu \mathrm{l}$ of the medium was added to the control wells. The plates were incubated for $48 \mathrm{~h}$. After $48 \mathrm{~h}$, adherent cell cultures were fixed by adding $50 \mu \mathrm{l}$ of cold $50 \%$ (w/v) trichloroacetic acid and incubating for $60 \mathrm{~min}$ at $4^{\circ} \mathrm{C}$. The supernatant was then discarded, and the plates were washed 5 times with de-ionized water and then dried. $100 \mu \mathrm{l}$ of SRB solution $(0.4 \% \mathrm{w} / \mathrm{v}$ in $1 \%$ acetic acid) was added to each microtiter well, and the culture was incubated for $30 \mathrm{~min}$ at room temperature for the complete staining reaction. Unbound SRB was removed by washing five times with $1 \%$ acetic acid and then the plates were air-dried. Bounded stain was solubilized with Tris buffer (10 mM) and the optical densities were read on an automated spectrophotometric plate reader (Molecular Devices, USA) at a wavelength of $492 \mathrm{~nm}$, and optical density (OD) of SRB in each well is directly proportional to the cell number. The experiment was performed in triplicate, and the mean SRB absorbance was taken for the calculation of inhibition. Percentage inhibition was calculated by comparing the OD of control well (Table 3) with that of test sample $[16,17]$

\section{Statistical analysis}

The experiment was performed in triplicate and the data are given as mean SRB absorbance for the calculation of inhibition \pm standard error of the mean. Percentage inhibition was calculated by comparing the OD of control well with that of test sample Fig.1:
Table 2: LCMS analysis of AS seed extract

\begin{tabular}{ll}
\hline Retention time range (min.) & Mass-to-charge $(\mathbf{m} / \mathbf{z})$ \\
\hline $2.3-2.5$ & 181.10 \\
$6.3-6.6$ & 313 \\
$7.0-7.3$ & 327 \\
$8.2-8.7$ & 652 \\
$9.9-10.3$ & 848 \\
$12.9-13.2$ & 837.30 \\
$15.0-15.4$ & 549.10 \\
$16.1-16.5$ & 269.10 \\
$18.3-18.7$ & 635.40 \\
$18.9-19.2$ & 656.40 \\
$19.9-20.1$ & 654.40 \\
$11.7-12.1$ & 832.40 \\
$21.7-22.2$ & 638.40 \\
$24.4-24.6$ & 638.40 \\
$25.2-25.7$ & 638.40 \\
\hline
\end{tabular}

LCMS: Liquid chromatography and mass spectroscopy, AS: Annona squamosa

Table 3: Anticancer activity of hydroalcoholic extract of AS

\begin{tabular}{lll}
\hline $\begin{array}{l}\text { Type of cell } \\
\text { line }\end{array}$ & Concentration of Extract $(\boldsymbol{\mu g} / \mathbf{m l})$ & \% inhibition \\
\hline MCF 7 & 100 & 53.34 \\
SiHa & 100 & 67.15 \\
HT & 100 & 67.66 \\
Ovcar & 100 & 69.72 \\
HepG2 & 100 & 63.82 \\
\hline
\end{tabular}

AS: Annona squamosal, MCF 7: Breast cancer cell line, SiHa: Cervix cancer cel line, HT: Colon cancer cell line, Ovcar: Ovary cancer cell line, HepG2: Liver cancer cell line

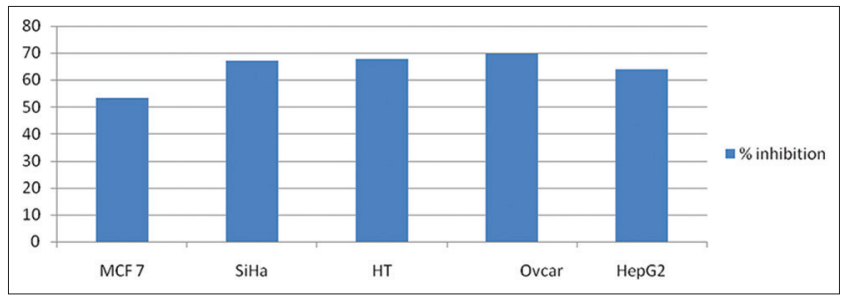

Fig. 1: Anticancer activity of hydroalcoholic extract of Annona squamosa

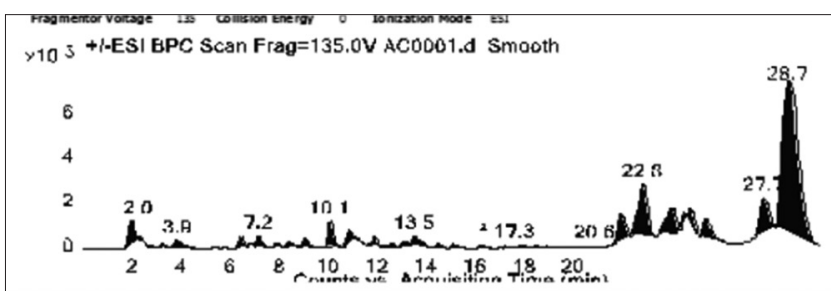

Fig. 2: Liquid chromatography and mass spectroscopy chromatogram of hydroalcoholic extract of Annona Squamosa

Inhibition $(\%)=\left(1 \frac{\text { Optical density of the treated cells }}{\text { Optical density of the control }}\right) \times 100$ 


\section{RESULTS AND DISCUSSIONS}

The percentage yield of the extract of seeds of AS was 16.83 (Table 1). It showed the presence of flavonoids, tannins, alkaloids, and other phytochemicals. The LCMS analysis revealed the presence of 15 different molecular weight compounds at different retention time (Table 2 and Fig.2). The mass spectrum of extract by LC-MS showed various peak of different peak of 15 compounds of which molecular ion peak at m/z 316 which resembles the molecular weight of the Isorhamnetin. However isohamnetin is methylated metabolite of quercetin which may acting as flavonoid in hydroalcoholic extract of extract of seeds of AS. The extract showed an average in vitro anticancer activity at a concentration of $100 \mu \mathrm{g} / \mathrm{ml}$ against all cancer cell lines. The best activity was observed against Ovcar cell line (69.72) and was also significant against HT and SiHa cell lines (Table 3). The anticancer activity of the plant may be due to the presence of phytochemicals, such as flavonols and flavonoids, which were investigated to determine chemoprevention activity against cancer [18]. Phenols, flavonoids, quercetin, genistein, and baicalein obtained from plant extracts are also effective against tumor [19]. Similarly, alkaloids such as schischkinnin and montamine have been isolated from the seeds of Centaurea schischkinii and Centaurea montana showed anticancer property [20]. Further, the active compounds of the plant can be isolated and their individual activity can be analyzed for several pharmacological activities.

\section{CONCLUSION}

On the basis of phytochemical and anticancer activity, it has been found that the Annona Squamosa seeds indicates potential against ovarian cancer cell lines. Phytochemical analysis indicates the presence of flavonoids and its derivatives are present in the Annona Squamosa seeds and can be concluded that anticancer potential may be due to presence of isohamnetin.

\section{AUTHOR CONTRIBUTIONS}

Sarvesh paliwal planned, design and supervised the research and manuscript. Shuchi Dave Mehta involved the design of the research, interpretation of data, analysis of the result and to the writing of the manuscript

\section{CONFLICT OF INTERESTS}

The authors declare that there is no conflict of interests regarding the publication of this paper.

\section{REFERENCES}

1. Akindele AJ, Wani ZA, Sharma S, Mahajan G, Satti NK, Adeyemi OO, et al. In vitro and in vivo anticancer activity of root extracts of Sansevieria liberica Gerome and labroy (Agavaceae). Evid Based
Complement Alternat Med 2015;2015:560404

2. Ochwang'i DO, Kimwele CN, Oduma JA, Gathumbi PK, Mbaria JM, Kiama SG. Medicinal plants used in treatment and management of cancer in Kakamega county, Kenya. J Ethnopharmacol 2014;151:1040-55.

3. Bhanot A, Sharma R, Noolvi MN. Natural sources as potential anticancer agents: A review. Int J Phytomed 2011;3:9-26.

4. Veerakumar S, Amanulla SD, Ramanthan K. Anti-cancer efficacy of ethanolic extracts from various parts of Annona squamosa on MCF-7 cell line. J Pharmacogn Phytother 2016;8:147-54.

5. Shaikh R, Pund M, Dawane A, Iliyas S. Evaluation of anticancer, antioxidant, and possible anti-inflammatory properties of selected medicinal plants used in Indian traditional medication. J Tradit Complement Med 2014;4:253-7.

6. Akerele O. Medicinal plants and primary health care: An agenda for action. Fitoterapia 1988;59:355-63.

7. Carocho M, Ferreira IC. The role of phenolic compounds in the fight against cancer-a review. Anticancer Agents Med Chem 2013;13:1236-58.

8. Ghasemzadeh A, Ghasemzadeh N . Flavonoids and phenolic acids: Role and biochemical activity in plants and human. J Med Plants Res 2011;5:6697-703.

9. Batra P, Sharma AK. Anticancer potential of flavonoids: Recent trends and future perspectives . Biotechnology 2013;3:439-59.

10. Zygmunt B, Namiesnik J. Preparation of samples of plant material for chromatographic analysis. J Chromatogr Sci 2003:41:109-16.

11. Trease GE, Evans WC. A Textbook of Pharmacognosy. $11^{\text {th }}$ ed. London: Bailliere Tindall; 1978 . p. 530

12. Kokate CK. Pharmacognosy. $16^{\text {th }}$ ed. Mumbai, India: Nirali Prakasham; 2001. p. 112

13. Shindle DB, Koratkar SS, Sharma N, Shitole A. Antioxidant activity and anti-proliferative action of methanolic extract of liquorice (Glycyrrhiza glabra) in HepG2 cell line. Int J Pharm Pharm Sci 2016;8:293-8.

14. Ibrahim K, Laurian V, Doina L, Ndreia C, Bianca I, Mihaiioan L. HPLC-MS study of phytoestrogens from Glycyrrhiza glabra. Farmacia 2010;58:89-94.

15. Monks A, Scudiero D, Skehan P, Shoemaker R, Paull K, Vistica D, et al. Feasibility of a high-flux anticancer drug screen using a diverse panel of cultured human tumor cell lines. J Natl Cancer Inst 1991;83:757-66.

16. Thanekar DR, Tupe P, Dhodi B, Juvekar AR. Evaluation of in vitro cytotoxic activity of petroleum ether and methanol extract of Mentha arvensis (whole plant) on human cancer cell lines. Int J Pharm Pharm Sci 2014;6:169-72

17. Singh S, Mehta A, Baweja S, Ahirwal L, Mehta P. Anticancer activity of Andrographis paniculata and Silybum marianum on five human cancer cell lines. J Pharmacol Toxicol 2013;8:42-8.

18. Conese M, Blasi F. The urokinase/urokinase-receptor system and cancer invasion. Baillieres Clin Haematol 1995;8:365-89.

19. Yoshida M, Sakai T, Hosokawa N, Marui N, Matsumoto K, Fujioka A, et al. The effect of quercetin on cell cycle progression and growth of human gastric cancer cells. FEBS Lett 1990;260:10-3.

20. Shoeb M, MacManus SM, Jaspars M, Trevidadu J, Nahar L, Thoo LP, et al. Montamine, a unique dimeric indole alkaloid, from the seeds of Centaurea montana (Asteraceae), and it's in vitro cytotoxic activity against the colon cancer cells. Tetrahedron 2006;62:11172-7. 